\title{
Variation in yield components and vegetative traits in Malaysian oil palm (Elaeis guineensis jacq.) dura $\times$ pisifera hybrids under various planting densities
}

\begin{abstract}
A long term evaluation of a planting density trial on selected 15 dura $\times$ pisifera oil palm hybrids from six Malaysian seed producers was laid out in equilateral triangle in four planting densities, namely 120 (D1), 148 (D2-Control), 170 (D3) and 215 (D4) palms/ha at the Malaysian Palm Oil Board (MPOB) Ulu Paka Research Station, Terengganu, Malaysia. Data on fresh fruit bunch (FFB), bunch number (BNO), bunch weight $(\mathrm{ABW})$, fruit/bunch $(\mathrm{F} / \mathrm{B})$, oil/bunch $(\mathrm{O} / \mathrm{B})$, frond production (FP), rachis length (RL) and palm height (HT) were collected from 1987 to 2003. Analysis of variance (ANOVA) of pooled data over years and densities showed significant differences among progenies $(\mathrm{G})$ and agencies (A) for all traits, reflecting their varying genetic backgrounds. Variations in planting densities (D) were significant for $\mathrm{ABW}, \mathrm{F} / \mathrm{B}$ and FP. Statistical differences were detected in $\mathrm{G} \times \mathrm{D}$ interactions for $\mathrm{ABW}, \mathrm{RL}$ and $\mathrm{FP}$ and $\mathrm{A} \times \mathrm{D}$ interaction for $\mathrm{ABW}$. FFB yield among agencies ranged from 18.4 to $21.5 \mathrm{t} / \mathrm{ha} / \mathrm{yr}$. The highest $\mathrm{BNO}$ was obtained from agency A2. Oil per bunch varied from 25.9 to 28.2\%; the highest was observed in Agency A1. HT of the 20-year old palms pooled over planting densities ranged from 8.99 (Agency A1) to $10.02 \mathrm{~m}$ (Agency A5) with the height increment (HI) among agencies ranged from 50 to $56 \mathrm{~cm} / \mathrm{yr}$. Variation for HT among densities was between $8.70 \mathrm{~m}$ (D1) and $10.43 \mathrm{~m}$ (D4) with height increment between $48.3 \mathrm{~cm} / \mathrm{yr}$ and $58 \mathrm{~cm} / \mathrm{yr}$. FP ranged from 17.1 (D4) to 19.1 (D1) fronds/yr while RL ranged from 6.20 (D1) to $6.86 \mathrm{~m}$ (D4). Density D2 (Control) recorded the highest FFB (21.7 t/ha/yr) followed by D3 (20.9 t/ha/yr), D4 (19.2 t/ha/yr), and D1 (18.6 t/ha/yr). Generally, HT was significantly and positively correlated with FFB components. FP also associated positively with HT and ABW. RL showed negative correlation with FP across all planting densities but generally has no association with FFB and O/B. In this trial, density 2 (148 palms/ha) was the ideal planting density for maximum FFB and oil yield $(6.0 \mathrm{t} / \mathrm{ha} / \mathrm{yr})$ per unit land area on inland soil and has been the standard practice of the oil palm industry.
\end{abstract}

Keyword: Planting density; Phenotypic traits; Correlation; Hybrid; Oilpalm 